Marquette University

e-Publications@Marquette

College of Education Faculty Research and

Publications

Education, College of

8-1-2004

Similarities and Differences in Role Conflict, Role Commitment, and Job Satisfaction for Female and Male High School Principals

Ellen Eckman

Marquette University, ellen.eckman@marquette.edu

Accepted version. Educational Administration Quarterly, Vol. 40, No. 3 (August 2004): 366-387.

Permalink. (C) 2004 SAGE Publications. Used with permission. 


\title{
Similarities and Differences in Role Conflict, Role Commitment, and Job Satisfaction for Female and Male High School Principals
}

\author{
Ellen Wexler Eckman \\ Educational Policy and Leadership, Marquette University \\ Milwaukee, WI
}

\begin{abstract}
The purpose of this study was to determine the effect of gender, role conflict, role commitment, and job satisfaction on the high school principal. Data were collected from high school principals in three midwestern states. The results indicated that there are differences between female and male high school principals in their personal and professional attributes as well as in role conflict. There were similarities between female and male high school principals in terms of role commitment and job satisfaction.
\end{abstract}

Women in the upper echelons of educational administration, such as the superintendency and principalship, find themselves in situations similar to those of women managers and executives in the corporate world. Both groups of women operate in male-dominated fields where descriptions of appropriate leadership behavior have been based on male models (Burke \& Nelson, 2002; Valentine, 1995). Burke and Nelson (2002) call for more research on women in management

Educational Administration Quarterly, Vol. 40, No. 3 (August 2004): pg. 366-387. DOI. This article is (C SAGE Publications and permission has been granted for this version to appear in e-Publications@Marquette. SAGE Publications does not grant permission for this article to be further copied/distributed or hosted elsewhere without the express permission from SAGE Publications. 
positions so that "professional women can understand why they are experiencing particular work situations" (p. 13). Likewise, scholars in educational administration have promoted the development of theory and research that would be more inclusive of women's perspectives (Edson, 1988; Schmuck, 1981; Shakeshaft, 1989).

A result of the increased interest in including women's experiences in educational administration theory has been the research on the few women who have succeeded in becoming superintendents (Blount, 1998; Brunner, 1999; Grogan, 1996; Tallerico, 1999). Yet, what is missing is research on the effect of gender on the high school principalship, for it is the high school principalship that has traditionally served as the career path to the superintendency (Goldberg, 1991; Ortiz, 1982; Schneider, 1986; Shakeshaft, 1989). Current research about the high school principalship continues to examine the participants as a group without considering the effect of gender (Gates, 2003; Roza \& Wishon, 2003).

It is within this context that I undertook this study of the high school principalship. In an effort to examine the relationship between gender, role conflict, role commitment, and job satisfaction on high school principals, this study explores the similarities and differences between female and male high school principals. An understanding of these similarities and differences continues the work of building a more inclusive theory of educational administration, adds to the knowledge base on the high school principalship, and identifies areas for further research.

\section{Background to the Study}

Shortage of Applicants for the High School Principalship

The Educational Research Service, along with the National Association of Elementary School Principals and the National Association of Secondary School Principals, documents a growing shortage of qualified candidates for the high school principalship in nearly all school districts in the United States (Houston, 1998; Protheroe, 2001; Young \& McLeod, 2001). Reasons given for this shortage of candidates include the unreasonable time demands and pressures on the principal, especially at the high school level, and the perception among potential candidates that one must be a "superman" to meet all of the expectations of the position (Protheroe, 2001). In 1994, the National Center for Education Statistics (NCES) reported

Educational Administration Quarterly, Vol. 40, No. 3 (August 2004): pg. 366-387. DOI. This article is (C) SAGE Publications and permission has been granted for this version to appear in e-Publications@Marquette. SAGE Publications does not grant permission for this article to be further copied/distributed or hosted elsewhere without the express permission from SAGE Publications. 
NOT THE PUBLISHED VERSION; this is the author's final, peer-reviewed manuscript. The published version may be accessed by following the link in the citation at the bottom of the page.

that $53.1 \%$ of secondary school teachers were female, whereas only $13.8 \%$ of the secondary school principals were female (Matthews \& Crow, 2003).

\section{Job Satisfaction}

Job satisfaction is considered an important and desirable goal for organizations because satisfied workers perform at higher levels than those who are not satisfied (Chambers, 1999). Knowledge of the factors that contribute to job satisfaction and the relationship of gender to job satisfaction is useful to policy makers in both business and educational institutions (Chambers, 1999; Burke, 2002).

Although there have been several studies of job satisfaction in the principalship, most of those studies have aggregated the data, not differentiating by gender and/or elementary or secondary school levels (Bacharach \& Mitchell, 1983; Fishel \& Pottker, 1979; Gross \& Trask, 1976; Malone, Sharp, \& Thompson, 2000). When researchers have focused on job satisfaction for high school principals, they have also aggregated the data and not considered the effect of gender (Derlin \& Schneider, 1994; Duke, 1988; Gunn \& Holdaway, 1986; Merrill \& Pounder, 1999; Rogus, Poppenhagen, \& Mingus, 1980).

There have been only a few studies examining job satisfaction where gender in the high school principalship was considered. Yet, these studies were limited by the scarcity of female high school principals. In a national study of educational administrators, Paddock (1981) reported that female high school principals were satisfied with their positions and would choose the same career. Fansher and Buxton (1984) found that female high school principals experienced higher levels of job satisfaction the older they were, the larger their school's enrollment, and the more positive the feedback they received from their students. To generalize findings on job satisfaction, it needs to be determined if both genders experience job satisfaction in the high school principalship in similar ways.

\section{Role Conflict}

Role conflict occurs as individuals attempt to balance their family and home roles with their professional roles. Work-time studies indicate that dual-earner families and single-parent families are working longer hours than ever and feeling more and more conflicted (Clarkberg \& Moen, 2001; Gerson \& Jacobs, 2001). Hochschild (1989)

Educational Administration Quarterly, Vol. 40, No. 3 (August 2004): pg. 366-387. DOI. This article is (C) SAGE Publications and permission has been granted for this version to appear in e-Publications@Marquette. SAGE Publications does not grant permission for this article to be further copied/distributed or hosted elsewhere without the express permission from SAGE Publications. 
described the "second shift" that faces working women at the end of the day as they turn to their personal roles as parents and wives. Napholz (1995a) found that working women experienced mental health issues as they struggled to balance their family needs with the demands of their jobs.

In their study of elementary and secondary school principals, Kochan, Spencer, and Mathews (2000) found that the primary issue facing both women and men was "managing their work and their time and coping with the stresses, tasks and responsibilities of the job" ( $p$. 305). Female principals mentioned twice as often as did male principals the enormity of the workload and the difficulty of "balancing everything" (p. 305). Several other researchers found that although conflicts between the demands of work and family affect both men and women, women experience greater work-family conflict than do men (Greenglass, Pantony, \& Burke, 1989; Riehl \& Byrd, 1997). More reasonable parameters need to be developed for the role of the principal, so that high school principals, regardless of gender, can manage the demands of their professional and personal lives (BorisSchacter \& Langer, 2002; Hurley, 2001; Riehl \& Byrd, 1997).

\section{Role Commitment}

Role commitment is defined as how individuals prioritize between their work and significant relationships. Burke (2002) noted that business organizations have two types of employees: (a) work committed or (b) personal life or family committed. They do not have employees who are equally committed to both work and family. He argued that as long as commitments to professional and personal roles are seen as either/or concepts, having a family would continue to be a career liability for many women. In studies of working women, Napholz (1995a) examined role commitment to further explain the nature of work-family conflicts. She found that women who chose either their work first or their significant relationships first had a lower level of role conflict than did the women who felt a need to commit to both work and significant relationships equally.

Researchers have also examined the effect of role commitment on educational administrators (Pavan, 1991). In a study that included 2 female and 48 male high school principals, Vadella and Willower (1990) found that a majority of the principals felt their commitment to their roles as high school principals had taken a toll on their families.

Educational Administration Quarterly, Vol. 40, No. 3 (August 2004): pg. 366-387. DOI. This article is (C SAGE Publications and permission has been granted for this version to appear in e-Publications@Marquette. SAGE Publications does not grant permission for this article to be further copied/distributed or hosted elsewhere without the express permission from SAGE Publications. 
Copland (2001) argued that the "myth of the superprincipal" has created such unreasonably high expectations for the role that it has become difficult for principals to maintain a balance between the commitments of their professional and personal lives. Kelly (1997) noted that female administrators resolved the issue of role commitment by being either success oriented with no marriage plans or being "superwomen" who were committed to both career and family.

\section{Effect of Role Conflict, Role Commitment, and Job Satisfaction}

The personal and professional attributes of the high school principal contribute to and affect the role dimensions of role conflict and role commitment, which in turn contribute to or affect job satisfaction (see Figure 1). This conceptual framework is based on prior research on these constructs (Burke, 2002; Copland, 2001; Eckman, 2002; Gross \& Trask, 1976; Kelly, 1997; Merrill \& Pounder, 1999; Napholz, 1995a; Riehl \& Byrd, 1997; Schneider, 1986).

In their synthesis of research findings on job satisfaction, Thompson, McNamara, and Hoyle (1997) found that as administrators experienced increases in role conflict, they reported decreases in overall job satisfaction. Although these results were based on data from educational administrators in general, the findings imply that job satisfaction for high school principals would be similarly affected by role conflict. The high school principals in Vadella and Willower's (1990) study identified the excessive time demands of the principalship as one of the most dissatisfying aspects of their position and one that led to conflicts between their personal and professional roles.

Role commitment is another role dimension that contributes to role conflict among high school principals. This study examines the interaction of role commitment with role conflict and job satisfaction in the high school principalship and the effect that gender plays.

\section{Methods and Procedures}

Female and male high school principals in Illinois, Minnesota, and Wisconsin were surveyed during 1999-2000. The names of the high school principals were obtained from the Illinois State Board of Education, the Minnesota Association of Secondary School Principals, 
the Minnesota State Department of Children, Families, and Learning, and the Wisconsin Department of Public Instruction. Survey packets containing questions on personal and professional attributes, along with three established questionnaires measuring role conflict, role commitment, and job satisfaction, were mailed to the participants. Included in the mailing was an explanatory letter, guaranteeing anonymity, and a postage paid self-addressed envelope.

At the time of the study, there were only 237 female high school principals in the 1,560 public high school districts in the three states. All of the women were asked to participate by completing the survey instrument. Of the 237 survey packets mailed to the women, 164 were returned, for a return rate of $69.2 \%$. To obtain an equivalent number of male participants, a random sample of male high school principals in the three states was selected $(N=327)$. Of the 327 survey packets mailed to men, 175 were returned, for a return rate of $53.5 \%$.

Three survey instruments were used in the study: a Role Conflict Questionnaire, a Role Commitment Question, and a Job Satisfaction Survey. The Role Conflict Questionnaire (Nevill \& Damico, 1974) is a nine-item Likert-type scale used to delineate areas of role conflict where participants indicate their level of conflict from 1 (not at all conflicted) to 7 (extremely conflicted). This instrument included questions relating to time for privacy, social commitments, and others; concerns over household management, finances, and child raising; and personal issues over expectations for self, others, and feelings of guilt. Scores ranged from 9 to 63 with higher scores in this instrument indicating a greater level of role conflict. This instrument has been used to measure individual well-being (Napholz, 1995b; Riesch, 1981). Cronbach alphas for this instrument have ranged from .70 to .73. For this study, the Cronbach alpha is .78.

The Role Commitment Question (Napholz, 1995a) is a one-item measure developed by Napholz to subjectively identify how working women set priorities for work and significant relationships. Napholz offered three discrete choices to her participants: (a) significant relationships first, (b) work equals relationship, and (c) work first. Differences were found based on an individual's role commitment (Napholz, 1995a). The question was modified for this study and participants were asked to identify their priorities for work or significant relationships by selecting the value on a 7-point scale from 1 (work first) to 7 (significant relationships first). This change enabled 
data to be used as an ordinal level measure as well as grouped into three categories.

The Job Satisfaction Survey (Mendenhall, 1977; Schneider, 1984 ) is a 27-item questionnaire that was tested and used to study the job satisfaction of female and male educators. For the purposes of this study, modifications were made to the text of 5 items to make them appropriate for high school principals. This instrument included questions relating to community relations, work conditions, financial rewards, relationships with supervisors, coworkers, and pupils, school characteristics, and career opportunities. Participants used a 4-point Likert-type scale to indicate their degree of satisfaction from 1 (very dissatisfied) to 4 (very satisfied). The range of scores was from 27 to 108; higher numbers indicated more job satisfaction. Rice and Schneider (1994) reported the overall scale reliability to be .90 . The Cronbach alpha for this study was .90 .

\section{Data Analysis}

This article addresses the relationship between role conflict, job satisfaction, and role commitment as experienced by female and male high school principals. Role conflict and job satisfaction were operationalized by creating summative scores from the established survey instruments. Statistical tests were performed with role conflict and job satisfaction as dependent variables. Role commitment was a one-question Likert-type response. This variable was examined as an ordinal value and then classified as a nominal variable for comparison with other studies. Pearson product moment correlation coefficients were calculated to examine the association between interval variables; $t$ tests were performed to examine the differences between the dependent variables based on gender. A two-way ANOVA was used to examine the relationship of the dependent variables with gender and role commitment groups. A stratification was applied when an interaction was found. For this study, effect sizes were included for significant findings and classified according to Lipsey (1990) as small (.13), medium (.47), and large (.73).

\section{Findings}

The findings on personal and professional attributes of the female and male high school principals are presented first, followed by the findings related to role conflict, role commitment, and job

Educational Administration Quarterly, Vol. 40, No. 3 (August 2004): pg. 366-387. DOI. This article is (C) SAGE Publications and permission has been granted for this version to appear in e-Publications@Marquette. SAGE Publications does not grant permission for this article to be further copied/distributed or hosted elsewhere without the express permission from SAGE Publications. 
NOT THE PUBLISHED VERSION; this is the author's final, peer-reviewed manuscript. The published version may be accessed by following the link in the citation at the bottom of the page.

satisfaction. Then role conflict, role commitment, and job satisfaction are described in terms of their interactions.

\section{Personal Attributes}

\section{Age and ethnicity}

The male and female high school principals in this study shared similar attributes in terms of ethnicity and age (see Table 1 ). None of the male participants were non-White as compared to $9.5 \%$ of the female participants (Fishers Exact Test, $p<.001$ ). The male high school principals were on average 48.13 years old $(S D=7.65)$ and the female high school principals were on average 47.41 years old ( $S D=$ 7.79). There were no significant differences between the current ages of the groups $(t=.48, d f=326, p=.62)$.

\section{Family structure}

Significant differences between the male and female high school principals were found in terms of the characteristics of their families. Ninety-three percent of the male participants indicated that they were currently married as compared to $67.9 \%$ of the female high school principals (Chi-square $=32.89, d f=1, p<.001$ ). Ninety-five percent of the male high school principals reported having children as compared to $75 \%$ of the female high school principals (Chi-square = 24.54, $d f=1, p<.001)$. Fifty-nine percent of the male high school principals reported having children living at home as compared to $23.5 \%$ of the women (Chi-square $=44.64, d f=1, p<.001$ ).

\section{Professional Attributes}

Differences were found between female and male high school principals on several professional and career characteristics (see Table 2 ). There was a significant difference in the number of years of teaching experience for the female and male high school principals ( $t$ $=2.49, d f=335, p=.014$, effect size $=.26)$. The average number of years of teaching experience for the male high school principals was 11.37 ( $S D=6.19)$. The average number of years of teaching experience for the female high school principals was 13.11 years (SD $=6.72$ ). There was a significant difference in the age for the first high school principalship, with men obtaining their first high school principalship at a younger age than women $(t=4.45, d f=320, p<$ 
.001 , effect size $=.34)$. Both the men and the women first became high school principals between the ages of 24 and 56 . The mean age for first principalship position for the men was 38.60 years $(S D=$ $7.20)$, whereas for the women the mean age was $42.10(S D=6.88)$.

\section{Age at first principalship}

To better examine the relationship between gender and age at the time of the first principalship position, the group was divided by age into quartiles. The age groupings were as follows: (a) ages 24 to 35, (b) ages 36 to 41 , (c) ages 42 to 45 , and (d) ages 46 and older. Thirty-six percent of male high school principals received their first principalship position between the ages of 24 and 35, as compared to only $16 \%$ of the female high school principals; whereas only $19 \%$ of the men obtained their first principalship after the age of 46 , as compared to $33 \%$ of the women (Chi-square $=19.3, d f=3, p<$ $.001)$.

\section{First high school principalship}

There was a significant difference in the percentage of women and men who were in their first position as high school principals at the time of the study (Chi-square $=9.59, d f=1, p<.001$ ). Seventythree percent of the women were high school principals for the first time as compared to $57 \%$ of the men who were high school principals for the first time. Regardless of whether this was their first high school principalship or not, male high school principals had been in their current positions significantly longer than their female counterparts ( $t$ $=4.35, d f=328, p<.001$, effect size $=.47)$. The female high school principals were in their present positions on average 4.32 years ( $S D=$ 2.99), with 14 years being the maximum. The male high school principals were in their present positions for an average of 6.70 years $(S D=6.30)$, with 32 being the maximum number of years in the position (see Table 3 ).

\section{Mobility}

An unwillingness to move to accept a position as a high school principal has been thought of as a contributing factor to the shortage of qualified applicants. In this study, female and male high school principals indicated a similar willingness to move to a new community or state to accept a high school principalship. Fifty-eight percent of the 
men indicated a willingness to move for a position as a high school principal as compared to $53 \%$ of the women who indicated a willingness to move. There was no significant difference in career mobility based on gender alone (Chi-square $=.925, d f=1, p=.34$ ). However, male and female high school principals differed in career mobility based on their marital status. Sixty-six percent of unmarried women (never married, divorced, or widowed) were willing to move as compared to $46 \%$ of the married women (Chi-square $=5.079, d f=1$, $p=.024)$. This difference was not true for men; $61 \%$ of the unmarried men indicated a willingness to move and $57.9 \%$ of the married men were willing to move (Chi-square $=.067, d f=1, p=.796$ ).

Despite the expressed willingness to move indicated by the majority of the male and female high school principals, they in fact did not have to move to accept their first position as high school principals. Seventy-six percent of the women and $52 \%$ of the men stated that they had not moved to accept their first position as a high school principal. A significantly higher percentage of the female high school principals had secured their present high school position in the same district in which they were currently employed as compared to the male high school principals (Chi-square $=10.14, d f=1, p<.001$ ). Only $35.5 \%$ of the men were hired as high school principals in the same district where they were currently employed, whereas $52.8 \%$ of the women were hired for their principalship in the district where they were currently employed.

\section{Aspirations}

There were no significant differences between women and men with regard to aspirations for the position of superintendent. Regardless of gender, a majority of the participants did not aspire to the superintendency. Only $45 \%$ of the male high school principals and $40 \%$ of the female high school principals indicated that they were interested in becoming superintendents (Chi-square $=.933, d f=1, p$ $=.334)$.

\section{Role Commitment}

To measure role commitment, the participants were asked to prioritize their work and relationship roles by placing themselves on a 7-point continuum from 1 (work first) to 7 (significant relationships first). There was no significant difference between the men and women

Educational Administration Quarterly, Vol. 40, No. 3 (August 2004): pg. 366-387. DOI. This article is (C SAGE Publications and permission has been granted for this version to appear in e-Publications@Marquette. SAGE Publications does not grant permission for this article to be further copied/distributed or hosted elsewhere without the express permission from SAGE Publications. 
on their responses to the role commitment question $(t=.71, d f=$ $302, p=.48)$. The average response for female high school principals was $4.54(S D=1.74)$. The average response for male high school principals was $4.68(S D=1.56)$.

To examine these data relative to other studies, the responses to the role commitment question were grouped into three categories. Responses of 1 and 2 were considered work first; responses of 3, 4, and 5 were considered work equals relationships; and responses of 6 and 7 were considered significant relationships first. There was no significant difference between the female and male high school principals based on their classification into these three categories (Chisquare $=5.31, d f=2, p=.07)$. Thirty-six percent of both the male and female high school principals chose significant relationships first. With regard to work first, $10 \%$ of the men made this choice as compared to $19 \%$ of the women.

\section{Role Conflict}

The Role Conflict Questionnaire was used to quantify the magnitude of role conflict for high school principals. Participants were asked to indicate their level of role conflict based on a 7-point Likerttype scale from 1 (not at all) to 7(extremely conflicted). For the total role conflict score, female high school principals scored on average $4.04(S D=1.01)$. For the total role conflict score, male high school principals scored on average $3.89(S D=1.02)$. There was no significant difference in role conflict scores between the female and male high school principals ( $t=1.44, d f=333, p=.150)$.

In addition, an item analysis was performed to achieve greater insight into role conflict in relationship to gender. The nine questions on which the participants were asked to rate their level of role conflict included (a) time for privacy, (b) time for social commitments, (c) time for significant others, (d) household management issues, (e) financial issues, (f) child-raising issues, $(g)$ expectations of self, $(h)$ expectations of others, and (i) feelings of guilt. On a scale of 1 to 7 , the group as a whole expressed a level of conflict greater than or equal to 4 on the questions concerning time for privacy, time for social commitments, meeting expectations for self, feelings of guilt, and household management.

Significant differences were found in the responses to four of the nine items on the Role Conflict Questionnaire. The female high school 
principals expressed significantly higher levels of conflict than did the male high school principals on the questions concerning time for social commitments, household management issues, and the ability to fulfill self-expectations. The question about monetary concerns was the only item where the male high school principals indicated significantly higher levels of conflict than did the female high school principals (see Table 4). There was a medium effect size for financial issues, a moderate effect size for expectations of self and time for social commitments, and a small to moderate effect size for household management issues (Lipsey, 1990).

To better understand the relationship between role conflict and role commitment, a one-way analysis of variance was performed for the entire group with the role commitment groups as the independent variable (see Table 5). A significant difference was found between the level of role conflict for the three categories of role commitment for high school principals. High school principals who chose work first ( $M$ $=4.48, S D=.97)$, experienced higher levels of role conflict than did the high school principals who chose either work and relationships equally $(M=4.02, S D=.96)$, or significant relationships first $(M=$ 3.75, $S D=1.05)$.

A two-way analysis of variance was performed to further examine the relationship of role conflict, role commitment, and gender. A significant interaction was found between female and male high school principals based on their role commitment category, $F(2$, 304) $=3.57, p=.029$ (see Table 6).

Because of the significant interaction between gender and role commitment, a stratified analysis was performed. For the men, there was a significant difference in role conflict based on role commitment, $F(2,152)=10.24, p<.001$, although there was a small effect size (see Table 7). The men who indicated work first had an average score for role conflict of $4.83(S D=.97)$, which was significantly higher than the male participants indicating work equals relationships $(M=3.90$, $S D=.90)$ and those who indicated significant relationships first $(M=$ $3.55, S D=1.09)$. There was no significant difference in role conflict based on role commitment for the female high school principals, $F(2$, $146)=1.07, p=.343$. 


\section{Job Satisfaction}

The Job Satisfaction Survey was a 27-item questionnaire.

Participants used a 4-point Likert-type scale to indicate their degree of satisfaction with their job, from 1 (very dissatisfied) to 4 (very satisfied). The female high school principals scored on average 2.83 $(S D=.38)$. The male high school principals scored on average 2.89 $(S D=.34)$. There was no significant difference between the average response for female and male high school principals on the job satisfaction survey $(t=1.36, d f=334, p=.17)$.

A one-way analysis of variance was performed to examine the relationship of the three levels of role commitment with job satisfaction. There was no significant difference in job satisfaction based on role commitment, $F(2,301)=.81, p=.45$, with effect size $=.005$. Further analysis using a two-way analysis of variance to examine the relationship of job satisfaction based on gender and role commitment indicated that there was no significant difference in job satisfaction between female and male high school principals, $F(1,298)$ $=1.67, p=.263$, with only a small effect of .005. The mean scores for job satisfaction ranged from 2.83 to 2.95, indicating a moderate degree of job satisfaction for each of the role commitment groups (see Table 8).

\section{Correlations}

Job satisfaction was significantly and inversely related to role conflict for the entire group of high school principals $(r=-.388, p<$ $.001)$. The higher the levels of role conflict, the lower the level of job satisfaction. The association between role conflict and job satisfaction was examined by computing Pearson correlation coefficients.

The association of role conflict and job satisfaction with the demographic characteristics of age, age at first principalship, and years in the present principalship was examined. Role conflict was inversely related to age $(r=-.203, p<.01)$. The younger the high school principals (women and men combined), the more role conflict they experienced. The longer the participants served in their principalships, the higher the level of job satisfaction and the lower the level of role conflict. There was no association between job satisfaction and the current age of the participant (see Table 9). According to Cohen (1977), correlations of .3 are considered medium effect sizes

Educational Administration Quarterly, Vol. 40, No. 3 (August 2004): pg. 366-387. DOI. This article is (C) SAGE Publications and permission has been granted for this version to appear in e-Publications@Marquette. SAGE Publications does not grant permission for this article to be further copied/distributed or hosted elsewhere without the express permission from SAGE Publications. 
and correlations of .5 are considered large effect sizes (Lipsey, 1990, p. 173).

\section{Discussion}

My investigation of the role of the high school principal began in search of an explanation for the disproportionately low representation of women in that position. Was there something about how women experienced role conflict, role commitment, and job satisfaction that explained why they were underrepresented in the high school principalship (Eckman, 2002)? I assumed that male high school principals handled role conflict, role commitment, and job satisfaction in ways that might better suit them for the position. To test this assumption, I needed to compare women and men as they experience the role of the high school principalship. The results of this study indicated that there are both similarities and differences between female and male high school principals in terms of their personal and professional attributes as well as their experiences of role conflict, role commitment, and job satisfaction.

Significant differences continue to appear between female and male high school principals in terms of their age at their first principalship, their years of teaching experience, their marital status, and the presence of children at home. The findings related to age are consistent with findings of previous studies that indicated women tend to be older when they obtain their first principalship and have more years of teaching experience than did men at their first principalship (NCES, 2000; Ortiz, 1982; Paddock, 1981; Schneider, 1986; Shakeshaft, 1989).

The male high school principals in this study have been in their positions for a longer period of time and have less teaching experience than the women, although both groups are currently the same age. This raises a question about why male educators enter high school administration at an earlier age than do female educators. One explanation for this finding may be that a "glass escalator" exists in female-dominated professions, like nursing and teaching, that quickly moves men up the career ladder (Williams, 2000). Another explanation for this phenomenon may be that role expectations for women and men create an environment in the high school where women teach and men lead (Marshall, 1997). 
The male high school principals had significantly higher concerns over financial issues than did the women. The higher levels of role conflict over monetary concerns may imply that men leave teaching positions for higher paying positions as high school principals earlier in their careers. It is not surprising that female high school principals experience higher levels of role conflict over household management (Hochschild, 1989). One result of trying to simultaneously manage their teaching, their families, and their homes may be that female educators delay attending to any aspirations they might have for the high school principalship.

Only $24 \%$ of the female high school principals had children at home, whereas $59 \%$ of the male high school principals had children at home. These data suggest that either women with children at home are not applying for the high school principalship or they are not being hired. Similarly, the finding that women are older at their first high school principalship suggests that women do not become high school principals until their children are grown and out of the house. Some researchers indicate that a bias exists among school board members and superintendents against hiring younger women as high school principals (Edson, 1988; Grady \& O'Connell, 1993; Marshall \& Mitchell, 1989; Pavan, 1991). Finally, the societal expectations of wife and mother may influence the choices made by younger female educators so as to keep them from aspiring for leadership positions.

There were some similarities between female and male high school principals found in this study. One surprising similarity had to do with career mobility. There is an assumption that women are less mobile in terms of their career choices than men and thus limited by geography in the high school principal positions they can actually pursue (Grady \& O'Connell, 1993; Paddock, 1981; Schneider, 1986). However, in this study, the participants, regardless of gender, expressed a similar willingness to move to a new community or state to become high school principals. There was no significant difference found in career mobility for unmarried male high school principals as compared to unmarried female high school principals. Marital status of the high school principal, rather than gender, may be the influencing factor in career mobility. This may be a result of the increasing number of two-career families in the workplace. In terms of attracting both men and women to high school principalships in new communities, cities, or states, attention will have to be given to the

Educational Administration Quarterly, Vol. 40, No. 3 (August 2004): pg. 366-387. DOI. This article is (C SAGE Publications and permission has been granted for this version to appear in e-Publications@Marquette. SAGE Publications does not grant permission for this article to be further copied/distributed or hosted elsewhere without the express permission from SAGE Publications. 
needs and desires of the candidates' partner and family regardless of the gender of the candidate. In addition, the data indicate that the female high school principals were more likely than the male high school principals to be hired in their own district. These findings should be considered by school board members as they seek ways to attract qualified applicants for the high school principalship (Protheroe, 2001).

It has been reported that female educational administrators have different and lower career aspirations than do male educational administrators (Blount, 1998; Fauth, 1984; Johnson, Yeakey, \& Moore, 1980; Paddock, 1981; Schneider, 1986; Shakeshaft, 1989). It is surprising that when asked about their interest in becoming superintendents, the female and male high school principals in this study shared similar attitudes with regard to their career aspirations. A majority of the participants were not interested in pursuing the position of superintendent. This contributes to the problem of attracting more applicants to the position of superintendent, because the high school principal position has been considered a direct career path to the superintendency (Ortiz, 1982; Schneider, 1986; Shakeshaft, 1989).

Both the female and male high school principals in this study experience role conflict as they struggle to balance their role commitments. On eight of the nine areas of the Role Conflict Questionnaire, the group as a whole rated their levels of conflict above the median response. In addition, as a group, the high school principals who chose work first experienced the highest levels of role conflict. The female high school principals were equally conflicted regardless of their role commitment. Although this finding was not consistent with Napholz's (1995a) findings, her participants were not administrators.

The male high school principals who selected work first found themselves facing more conflict with their families and personal lives than did those men who chose significant others first or those who committed to both equally. In choosing work first, the male high school principals may be responding to the increasing demands of the position by neglecting their families and thus experiencing more role conflict (Fenwick \& Pierce, 2001). The high school principals, both male and female, who select significant relationships first have made a clear choice that then results in a lower level of role conflict. Further research on the part that role commitment plays in role conflict for 
high school principals may enable policy makers and school board members to consider changes that would make the position more attractive.

Job satisfaction as a high school principal was similar for women and men; the two groups as a whole experienced only moderate levels of job satisfaction. Looking at job satisfaction is more complex than just comparing the mean scores. Job satisfaction and tenure as a high school principal were positively associated; the more years served as a high school principal, the higher the levels of job satisfaction. With men beginning their careers as high school principals at a younger age than women, they have more opportunity to experience satisfaction with their jobs. It is therefore surprising to find that male and female high school principals have no significant difference in their overall levels of job satisfaction at this point in time. Further analysis is needed to identify additional factors that contribute to job satisfaction so the high school principalship will be seen as a satisfactory position to both women and men.

The difficulty women and men have in balancing their personal lives and their professional lives as high school principals and the increased role conflict that comes with that struggle affect the future recruitment and retention of both women and men for the position. We will not be able to increase the pool of qualified applicants for the high school principalship until we begin to address issues of role conflict, role commitment, and job satisfaction.

Recently, there has been a discussion of redefining, reinventing, and/or reconceptualizing the role of the principal as a way to contribute to increasing the recruitment and retention of principals (Boris-Schacter \& Langer, 2002; Matthews \& Crow, 2003). Suggestions have included the following: creating smaller high schools, writing job descriptions that focus more on instructional leadership and less on management, increasing staff support, increasing the compensation package, improving the working conditions, revamping the principal preparation programs, providing mentors for new principals, and creating ongoing professional development opportunities for veteran principals (Ferrandino \& Tirozzi, 2001; Institute for Educational Leadership, 2000). It is also important to consider ways to provide family-friendly workplace policies that will allow high school principals, regardless of gender, to balance their personal and professional roles. If these types of changes are indeed 
implemented in our high schools, further research will be needed to ascertain if and how the reforms affect role conflict, role commitment, and job satisfaction for both female and male high school principals.

\section{Notes}

- Ellen Wexler Eckman is an assistant professor at Marquette University and her research interests are principals and female educational leaders. Her most recent publication is a 2003 article entitled "Voices of Women High School Principals" in Journal of Women in Educational Leadership.

\section{References}

Bacharach, S., \& Mitchell, S. (1983). The sources of dissatisfaction in educational administration: A role-specific analysis. Educational Administration Quarterly, 19(1), 101-128.

Blount, J. (1998). Destined to rule the schools: Women and the superintendency, 1873-1995. Albany: State University of New York Press.

Boris-Schacter, S., \& Langer, S. (2002). Caught between nostalgia and utopia. Education Week, 11(21), 34-37.

Brunner, C. C. (Ed.). (1999). Sacred dreams: Women and the superintendency. Albany: State University of New York Press.

Burke, R. (2002). Organizational culture: A key to the success of work and family programs. In R. Burke \& D. Nelson (Eds.), Advancing women's careers: Research and practice (pp. 287-309). Malden, MA: Blackwell Publishers.

Burke, R., \& Nelson, D. (2002). Advancing women in management: Progress and prospects. In R. Burke \& D. Nelson (Eds.), Advancing women's careers: Research and practice (pp. 3-15). Malden, MA: Blackwell Publishers.

Chambers, J. (1999). The job satisfaction of managerial and executive women: Revisiting the assumptions. Journal of Education for Business, 75(2), 69-74.

Clarkberg, M., \& Moen, P. (2001).Understanding the time-squeeze: Married couples' preferred and actual work-hour strategies. American Behavioral Scientist, 44(7), 1115-1136.

Cohen, J. (1977). Statistical power analysis for the behavioral sciences (2nd ed.). Hillsdale, NJ: Lawrence Erlbaum.

Copland, M. (2001). The myth of the superprincipal. Phi Delta Kappan, 82(7), 528-533.

Derlin, R., \& Schneider, G. T. (1994). Understanding job satisfaction: Principals and teachers, urban and suburban. Urban Education, 29(1), 63-88.

Educational Administration Quarterly, Vol. 40, No. 3 (August 2004): pg. 366-387. DOI. This article is (C) SAGE Publications and permission has been granted for this version to appear in e-Publications@Marquette. SAGE Publications does not grant permission for this article to be further copied/distributed or hosted elsewhere without the express permission from SAGE Publications. 
NOT THE PUBLISHED VERSION; this is the author's final, peer-reviewed manuscript. The published version may be

accessed by following the link in the citation at the bottom of the page.

Duke, D. (1988). Why principals consider quitting. Phi Delta Kappan, 70(4), 308-312.

Eckman, E. (2002). Women high school principals: Perspectives on role conflict, role commitment and job satisfaction. Journal of School Leadership, 12(1), 57-77.

Edson, S. (1988). Pushing the limits: The female administrative aspirant. Albany: State University of New York Press.

Fansher, T., \& Buxton, T. (1984). A job satisfaction profile of the female secondary school principal in the United States. National Association of Secondary School Principals Bulletin, 68(468), 32-39.

Fauth, G. (1984). Women in educational administration: A research profile. Educational Forum, 49(1), 65-79.

Fenwick, L., \& Pierce, M. C. (2001, March). The principal shortage: Crisis or opportunity? Principal [Online], 80(4). Available: www.naesp.org/comm/p0301a.htm

Ferrandino, V., \& Tirozzi, G. (2001). How do you reinvent a principal? Education Week, 20(20), 8-9.

Fishel, A., \& Pottker, J. (1979). Performance of women principals: Review of behavioral and attitudinal studies. In M. Berry (Ed.), Women in educational administration: A book of readings (pp. 24-31). Washington, DC: National Association for Women Deans, Administrators, and Counselors.

Gates, S. (2003). What evidence do we have of a crisis in school leadership? Paper presented at the annual meeting of the American Educational Research Association, Chicago, IL.

Gerson, K., \& Jacobs, J. (2001). Changing the structure and culture of work: Work and family conflict, work flexibility, and gender equity in the modern workplace. In R. Hertz \& N. Marshall (Eds.), Working families: The transformation of the American home (pp. 207-226). Berkeley: University of California Press.

Goldberg, C. (1991). A study of the career paths of administrators in central office positions in New York State public schools. (ERIC Document Reproduction Service No. ED 341 145)

Grady, M., \& O'Connell, P. (1993). Women in K-12 educational administration: A synthesis of dissertation research. Journal of School Leadership, 3, 449-460.

Greenglass, E. R., Pantony, K., \& Burke, R. J. (1989). A gender-role perspective on role conflict, work stress and social support. In E. B. Goldsmith (Ed.), Work and family (pp. 317-328). Newbury Park, CA: Sage.

Grogan, M. (1996). Voices of women aspiring to the superintendency. Albany: State University of New York Press.

Educational Administration Quarterly, Vol. 40, No. 3 (August 2004): pg. 366-387. DOI. This article is (C) SAGE Publications and permission has been granted for this version to appear in e-Publications@Marquette. SAGE Publications does not grant permission for this article to be further copied/distributed or hosted elsewhere without the express permission from SAGE Publications. 
NOT THE PUBLISHED VERSION; this is the author's final, peer-reviewed manuscript. The published version may be accessed by following the link in the citation at the bottom of the page.

Gross, N., \& Trask, A. (1976). The sex factor and the management of schools. New York: John Wiley \& Sons.

Gunn, J., \& Holdaway, E. (1986). Perceptions of effectiveness, influence, and satisfaction of senior high school principals. Educational Administration Quarterly, 22(2), 43-62.

Hochschild, A. (1989). The second shift: Working parents and the revolution at home. New York: Viking Press.

Houston, P. (1998). The ABC's of administrative shortages. Education Week, $17(38), 32-44$.

Hurley, J. (2001). The principalship: Less may be more. Education Week, 20(37), 37-39.

Institute for Educational Leadership. (2000, October). Leadership for student learning: Reinventing the principalship. A report of the Task Force on the Principalship, School Leadership for the 21st Century Initiative.

Johnson, G., Yeakey, C., \& Moore, S. (1980). An analysis of the employment of women in professional administrative positions in public education. Planning and Changing, 11(3), 115-132.

Kelly, R. M. (1997). Gender, culture and socialization. In D. Dunn (Ed.), Workplace/women's place: An anthology. Los Angeles: Roxbury Publishing Co.

Kochan, F., Spencer, W., \& Mathews, J. (2000). Gender-based perceptions of the challenges, changes, and essential skills of the principalship. Journal of School Leadership, 10(3), 290-310.

Lipsey, M. (1990). Design sensitivity: Statistical power for experimental research. Newbury Park, CA: Sage.

Malone, B., Sharp, W., \& Thompson, J. (2000). The Indiana principalship: Perceptions of principals, aspiring principals, and superintendents. Paper presented at the annual meeting of the Midwestern Educational Research Association, Chicago, IL. (ERIC Document Reproduction Service No. ED 44706)

Marshall, C. (Ed.). (1997). Feminist critical policy analysis: A perspective from primary and secondary schooling. Washington, DC: Falmer Press.

Marshall, C., \& Mitchell, B. (1989, March). Women's careers as a critique of the administrative culture. Paper presented at the annual meeting of the American Educational Research Association, San Francisco, CA. (ERIC Document Reproduction Service No. ED 307 675)

Matthews, L., \& Crow, G. (2003). Being and becoming a principal: Role conceptions for contemporary principals and assistant principals. Boston, MA: Allyn and Bacon.

Mendenhall, D. R. (1977). Relationship of organizational structure and leadership behavior to teacher job satisfaction in IGE schools (Tech. Rep. No. 412). Madison: Wisconsin Research and Development Center for Cognitive Learning.

Educational Administration Quarterly, Vol. 40, No. 3 (August 2004): pg. 366-387. DOI. This article is (C) SAGE Publications and permission has been granted for this version to appear in e-Publications@Marquette. SAGE Publications does not grant permission for this article to be further copied/distributed or hosted elsewhere without the express permission from SAGE Publications. 
NOT THE PUBLISHED VERSION; this is the author's final, peer-reviewed manuscript. The published version may be accessed by following the link in the citation at the bottom of the page.

Merrill, R., \& Pounder, D. (1999, November). Attraction and retention of high school principals. Paper presented at the annual meeting of the University Council of Educational Administration, Minneapolis, MN.

Napholz, L. (1995a). Indexes of psychological well-being and role commitment among working women. Journal of Employment Counseling, 32(1), 22-32.

Napholz, L. (1995b). Mental health and American Indian women's multiple roles. American Indian and Alaska Native Mental Health Research: Journal of the National Center, 6(2), 57-75.

National Center for Education Statistics (NCES). (2000). Educational equity for girls and women. Washington, DC: U.S. Department of Education, National Center for Education Statistics.

Nevill, D., \& Damico, S. (1974). Development of a role conflict questionnaire for women: Some preliminary findings. Journal of Consulting and Clinical Psychology, 42(5), 743.

Ortiz, F. (1982). Career patterns in education: Women, men and minorities in public school administration. New York: Praeger Publishers.

Paddock, S. (1981). Male and female career paths in school administration. In P. Schmuck, W. Charters, \& R. Carlson (Eds.), Educational policy and management: Sex differentials (pp. 187-198). New York: Academic Press.

Pavan, B. (1991, April). Reflections of female school administrators regarding their careers. Paper presented at the annual meeting of the American Educational Research Association, Chicago, IL. (ERIC Document Reproduction Service No. ED 334 676)

Protheroe, N. (2001). Attracting and retaining high quality people for the principalship: Problems and possibilities. Paper presented at the annual meeting of the American Educational Research Association, Seattle, WA.

Rice, E. M., \& Schneider, G. T. (1994). A decade of teacher empowerment: An empirical analysis of teacher involvement in decision making, 19801991. Journal of Educational Administration, 32(1), 43-58.

Riehl, C., \& Byrd, M. (1997). Gender differences among new recruits to school administration: Cautionary footnotes to an optimistic tale. Educational Evaluation and Policy Analysis, 19(1), 45-64.

Riesch, S. (1981). Occupational commitment, role conflict, and the quality of maternal-infant interaction. Unpublished doctoral dissertation, Rush University, Chicago, IL.

Rogus, J., Poppenhagen, B., \& Mingus, J. (1980). As secondary principals view themselves: Implications for principal preparation. High School Journal, 63(4), 167-172.

Educational Administration Quarterly, Vol. 40, No. 3 (August 2004): pg. 366-387. DOI. This article is (C) SAGE Publications and permission has been granted for this version to appear in e-Publications@Marquette. SAGE Publications does not grant permission for this article to be further copied/distributed or hosted elsewhere without the express permission from SAGE Publications. 
NOT THE PUBLISHED VERSION; this is the author's final, peer-reviewed manuscript. The published version may be accessed by following the link in the citation at the bottom of the page.

Roza, M., \& Wishon, S. (2003). The principal shortage: A problem of definition. Paper presented at the annual meeting of the American Educational Research Association, Chicago, IL.

Schmuck, P. (1981). The sex dimension of school organization: Overview and synthesis. In P. Schmuck, W. Charters, \& R. Carlson (Eds.), Educational policy and management: Sex differentials (pp. 221-234). New York: Academic Press.

Schneider, G. T. (1984). Teacher involvement in decision making: Zones of acceptance, decision conditions, and job satisfaction. Journal of Research and Development in Education, 18(1), 25-32.

Schneider, G. T. (1986). Career path and mobility differences of women and men in educational administration. Paper presented at the annual meeting of the American Educational Research Association, San Diego, CA.

Shakeshaft, C. (1989). Women in educational administration. Newbury Park, CA: Corwin Press.

Tallerico, M. (1999). Women and the superintendency: What do we really know? In C. C. Brunner (Ed.), Sacred dreams: Women and the superintendency (pp. 29-48). Albany: State University of New York Press.

Thompson, D., McNamara, J., \& Hoyle, J. (1997). Job satisfaction in educational organizations: A synthesis of research findings. Educational Administration Quarterly, 33(1), 7-37.

Vadella, R., \& Willower, D. (1990). High school principals discuss their work. NASSP Bulletin, 74(525), 108-118.

Valentine, P. (1995). Women's working worlds: A case study of a female organization. In D. Dunlap \& P. Schmuck (Eds.), Women leading in education (pp. 340-357). Albany: State University of New York Press.

Williams, C. (2000). The glass escalator: Hidden advantages for men in the "female" professions. In A. Minas (Ed.), Gender basics: Feminist perspectives on women and men (2nd ed., pp. 158-165). Belmont, CA: Wadsworth/Thomson Learning.

Young, M., \& McLeod, S. (2001). Flukes, opportunities, and planned interventions: Factors affecting women's decisions to become school administrators. Educational Administration Quarterly, 37(4), 462-502.

Educational Administration Quarterly, Vol. 40, No. 3 (August 2004): pg. 366-387. DOI. This article is (C) SAGE Publications and permission has been granted for this version to appear in e-Publications@Marquette. SAGE Publications does not grant permission for this article to be further copied/distributed or hosted elsewhere without the express permission from SAGE Publications. 
NOT THE PUBLISHED VERSION; this is the author's final, peer-reviewed manuscript. The published version may be accessed by following the link in the citation at the bottom of the page.

\section{Appendix}

Table 1. Personal Characteristics of Female and Male High School Principals

\begin{tabular}{|l|c|c|}
\hline & Percentage Fermale (n =161) & Percentage Male (n = 175) \\
\hline Married & 67.9 & 92.6 \\
\hline White & 90.5 & 100.0 \\
\hline Children & 75.0 & 95.0 \\
\hline Children living at home & 23.5 & 59.0 \\
\hline
\end{tabular}

Table 2. Means and Standard Deviations of Current Age, Age at First Principalship, and Years Worked as Teachers

\begin{tabular}{|l|c|c|c|c|}
\hline \multirow{2}{*}{} & \multicolumn{2}{|c|}{ Women $(\mathbf{n}=164)$} & \multicolumn{2}{c|}{ Men $(\mathbf{n}=175)$} \\
\cline { 2 - 5 } & Mean & SD & Mean & SD \\
\hline Age & 47.41 & 7.79 & 48.13 & 7.65 \\
\hline Age first principalship & 42.10 & 6.88 & 38.60 & 7.20 \\
\hline Years as teacher & 13.11 & 6.72 & 11.37 & 6.19 \\
\hline
\end{tabular}

Table 3. Mean Number of Years for Women and Men in their Current Positions as High School Principals

\begin{tabular}{|l|c|c|c|c|}
\hline \multirow{2}{*}{} & \multicolumn{2}{|c|}{ Women $(\mathrm{n}=160)$} & \multicolumn{2}{c|}{ Men $(\mathrm{n}=170)$} \\
\cline { 2 - 5 } & Mean & SD & Mean & SD \\
\hline Not the first principalship & 4.68 & 3.18 & 6.61 & 5.75 \\
\hline First principalship position & 4.18 & 2.94 & 6.83 & 6.72 \\
\hline Total & 4.32 & 2.99 & 6.70 & 6.29 \\
\hline
\end{tabular}

Educational Administration Quarterly, Vol. 40, No. 3 (August 2004): pg. 366-387. DOI. This article is (C) SAGE Publications and permission has been granted for this version to appear in e-Publications@ Marquette. SAGE Publications does not grant permission for this article to be further copied/distributed or hosted elsewhere without the express permission from SAGE Publications. 
NOT THE PUBLISHED VERSION; this is the author's final, peer-reviewed manuscript. The published version may be accessed by following the link in the citation at the bottom of the page.

Table 4. Means and Standard Deviations of Role Conflict Questions for Female and Male High School Principals

\begin{tabular}{|c|c|c|c|c|c|c|c|c|}
\hline & $\left(\begin{array}{l}T \\
=\end{array}\right.$ & $\begin{array}{l}\text { al } \\
335)\end{array}$ & $\begin{array}{l}\text { Fer } \\
(n=\end{array}$ & $\begin{array}{l}\text { ale } \\
60 \text { ) }\end{array}$ & $\underset{n=}{M}$ & $\begin{array}{l}\text { le } \\
\text { (75) }\end{array}$ & & Effect \\
\hline & Mean & SD & Mean & SD & Mean & SD & $t(d f=344)$ & Size \\
\hline Time for privacy & 4.99 & 1.55 & 5.13 & 1.54 & 4.86 & 1.56 & 1.59 & .18 \\
\hline $\begin{array}{l}\text { Time for social } \\
\text { commitments }\end{array}$ & 4.92 & 1.45 & 5.22 & 1.37 & 4.65 & 1.48 & $3.60^{* *}$ & .39 \\
\hline $\begin{array}{l}\text { Time for significant } \\
\text { others }\end{array}$ & 3.54 & 1.78 & 3.38 & 1.81 & 3.68 & 1.74 & 1.51 & .18 \\
\hline $\begin{array}{l}\text { Household } \\
\text { management }\end{array}$ & 3.69 & 1.64 & 3.89 & 1.64 & 3.51 & 1.63 & $2.08^{\circ}$ & .22 \\
\hline Financial issues & 2.63 & 1.55 & 2.20 & 1.38 & 2.99 & 1.59 & $4.63^{* \hbar}$ & .52 \\
\hline Child-raising issues & 3.95 & 1.89 & 3.98 & 2.00 & 3.93 & 1.81 & .196 & .02 \\
\hline Expectations of self & 4.18 & 1.68 & 4.50 & 1.71 & 3.89 & 1.60 & $3.40^{*}$ & 37 \\
\hline $\begin{array}{l}\text { Expectations of } \\
\text { others }\end{array}$ & 3.58 & 1.60 & 3.72 & 1.60 & 3.45 & 1.61 & 1.56 & .16 \\
\hline Feelings of guilt & 4.08 & 1.72 & 4.19 & 1.76 & 3.98 & 1.69 & 1.09 & .11 \\
\hline
\end{tabular}

${ }^{*} p<01, \cdots p<001$

Table 5. Analysis of Variance for Role Conflict by Role Commitment

\begin{tabular}{|l|c|c|c|c|c|}
\hline & df & Sum of Squares & Mean Square & $\mathrm{F}$ & $\mathrm{P}$ \\
\hline Between groups & 2 & 16.443 & 8.222 & 8.352 & $<.001$ \\
\hline Within groups & 301 & 296.298 & .984 & & \\
\hline Total & 303 & 312.742 & & & \\
\hline
\end{tabular}

Table 6. Means and Standard Deviations of Role Conflict for Women and Men Grouped by Role Commitment Question

\begin{tabular}{|l|c|c|c|c|c|c|}
\hline \multirow{2}{*}{} & \multicolumn{2}{|c|}{ Women $(\mathrm{n}=\mathbf{1 4 9})$} & \multicolumn{2}{c|}{ Men $(\mathrm{n}=\mathbf{1 5 5})$} & \multicolumn{2}{c|}{ Total $(\mathrm{n}=304)$} \\
\cline { 2 - 7 } & Mean & SD & Mean & SD & Mean & SD \\
\hline Work first & 4.28 & .93 & 4.83 & .97 & 4.48 & .97 \\
\hline Work equals relationships & 4.16 & 1.01 & 3.90 & .90 & 4.02 & .96 \\
\hline Significant relationships first & 3.96 & .96 & 3.55 & 1.09 & 3.75 & 1.05 \\
\hline & $\mathrm{df}$ & $\begin{array}{c}\text { Sum of } \\
\text { Squares }\end{array}$ & $\begin{array}{c}\text { Mean } \\
\text { Square }\end{array}$ & $\mathrm{F}$ & $\mathrm{p}$ & $\begin{array}{c}\text { Effect } \\
\text { Size }\end{array}$ \\
\hline Gender & 1 & .101 & .101 & .105 & .746 & .015 \\
\hline Role commitment & 2 & 18.507 & 9.254 & 9.638 & $<.001$ & .730 \\
\hline Gender X role commitment & 2 & 6.857 & 3.428 & 3.571 & .029 & .023 \\
\hline Residual & 298 & 234.802 & .960 & & & \\
\hline
\end{tabular}

Table 7. Analysis of Variance of Role Commitment and Role Conflict Mean Score

\begin{tabular}{|l|c|c|c|c|c|c|}
\hline \multicolumn{1}{|c|}{ Men } & df & Sum of Squares & Mean Square & F & P & Effect Size \\
\hline Between groups & 2 & 19.633 & 9.817 & 10.245 & $<.001$ & .119 \\
\hline Within groups & 152 & 145.645 & 959 & & & \\
\hline Total & 154 & 165.278 & & & & \\
\hline
\end{tabular}

Educational Administration Quarterly, Vol. 40, No. 3 (August 2004): pg. 366-387. DOI. This article is (C) SAGE Publications and permission has been granted for this version to appear in e-Publications@Marquette. SAGE Publications does not grant permission for this article to be further copied/distributed or hosted elsewhere without the express permission from SAGE Publications. 
NOT THE PUBLISHED VERSION; this is the author's final, peer-reviewed manuscript. The published version may be accessed by following the link in the citation at the bottom of the page.

Table 8. Mean Scores of Job Satisfaction With the Three Role Commitment Groups by Gender

\begin{tabular}{|l|c|c|c|c|c|c|}
\hline \multirow{2}{*}{} & \multicolumn{2}{|c|}{ Women $(\mathbf{n}=149)$} & \multicolumn{2}{c|}{ Men $(\mathrm{n}=155)$} & \multicolumn{2}{c|}{ Total $(\mathbf{N}=304)$} \\
\cline { 2 - 7 } & Mean & SD & Mean & SD & Mean & SD \\
\hline Work first & 2.84 & .43 & 2.85 & .34 & 2.85 & .40 \\
\hline Work equals relationships & 2.83 & .38 & 2.85 & .30 & 2.84 & .34 \\
\hline Significant relationships first & 2.84 & .39 & 2.95 & .41 & 2.90 & .40 \\
\hline
\end{tabular}

TABLE 9. Correlation Matrices of Demographic Variables, Job Satisfaction, and Role Conflict

\begin{tabular}{|l|c|c|c|c|}
\hline & $\begin{array}{c}\text { Job Satisfaction } \\
\text { Mean Score }\end{array}$ & $\begin{array}{c}\text { Role Conflict } \\
\text { Mean Score }\end{array}$ & Age & $\begin{array}{c}\text { Age at First } \\
\text { Principalship }\end{array}$ \\
\hline Role conflict mean score & $-.388^{* *}$ & & & \\
\hline Age & 0.34 & $-.203^{* *}$ & & \\
\hline Age at first principalship & -.065 & -.103 & $.558^{* *}$ & \\
\hline Years in present principalship & $.174^{* *}$ & $-.150^{* *}$ & $.414^{* *}$ & $-.225^{* *}$ \\
\hline
\end{tabular}

* Correlation is significant at the 01 level.

Figure 1: Relationship Between Role Conflict, Role Commitment, and Job Satisfaction for High School Principals

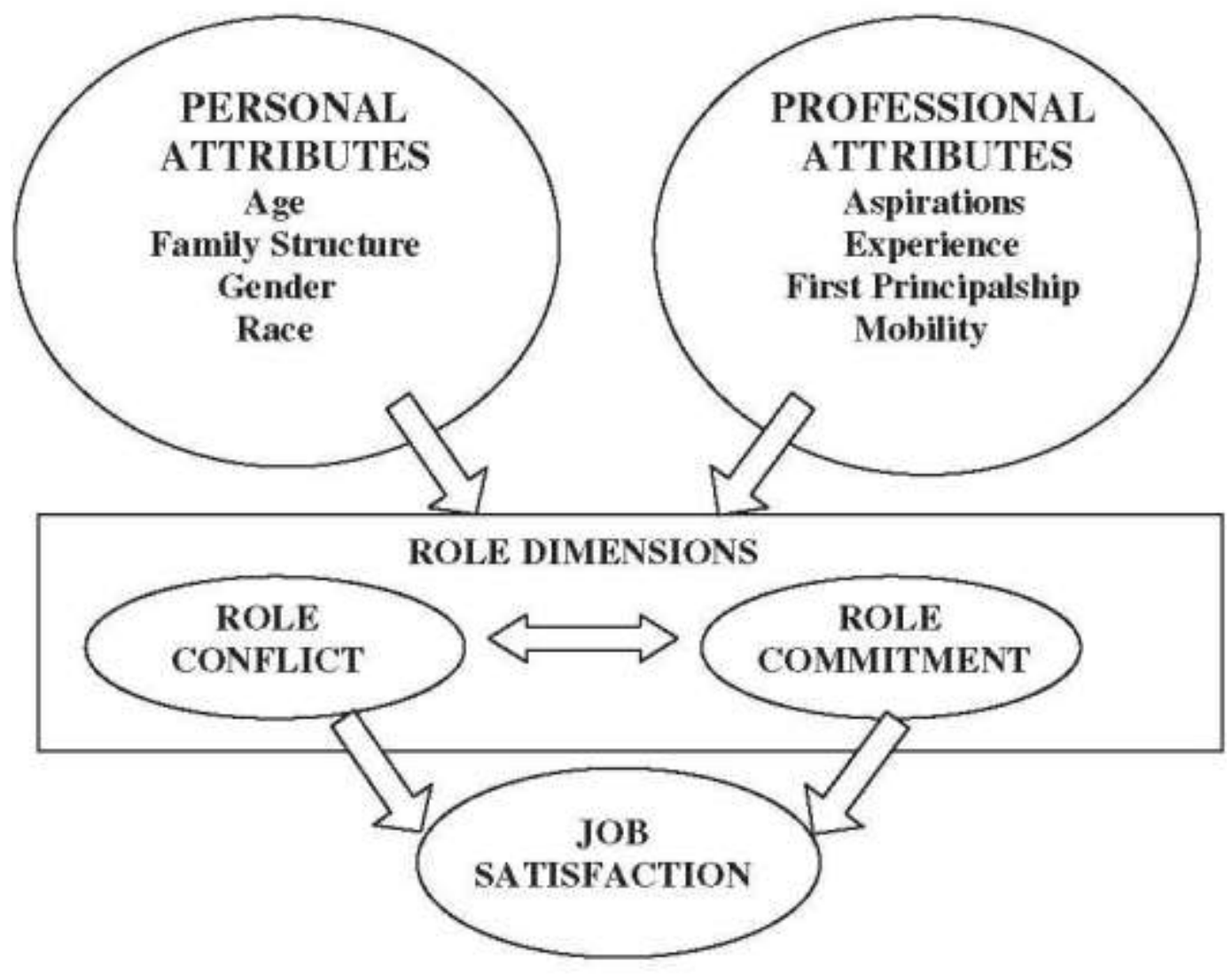

Educational Administration Quarterly, Vol. 40, No. 3 (August 2004): pg. 366-387. DOI. This article is (C) SAGE Publications and permission has been granted for this version to appear in e-Publications@Marquette. SAGE Publications does not grant permission for this article to be further copied/distributed or hosted elsewhere without the express permission from SAGE Publications. 
NOT THE PUBLISHED VERSION; this is the author's final, peer-reviewed manuscript. The published version may be accessed by following the link in the citation at the bottom of the page.

Educational Administration Quarterly, Vol. 40, No. 3 (August 2004): pg. 366-387. DOI. This article is (C SAGE Publications and permission has been granted for this version to appear in e-Publications@ Marquette. SAGE Publications does not grant permission for this article to be further copied/distributed or hosted elsewhere without the express permission from SAGE Publications. 